\title{
The Role of Communication in Creating Awareness About Electoral Opinion Polls in Kenya
}

\author{
Wambua Paul \\ Assistant Lecturer, Faculty of Media and Communication, \\ Multimedia University of Kenya; \\ Ndeti Ndati \\ Senior Lecturer, School of Journalism and Mass Communication, \\ University of Nairobi Kenya; \\ Muthini Faith \\ Assistant Lecturer, Faculty of Media and Communication, \\ Multimedia University of Kenya; \\ Samuel Siringi \\ Lecturer, School of Journalism, University of Nairobi.
}

doi: 10.19044/esj.2016.v12n35p301 URL:http://dx.doi.org/10.19044/esj.2016.v12n35p301

\begin{abstract}
The key objective of this study was to investigate the role of communication in creating awareness on electoral opinion polls in Kenya. The study adopted descriptive survey design. It targeted the four main pollsters (that deal with electoral opinion polls) in Kenya. These are: Ipsos Synovate, Strategic Africa, Consumer Insight and Infotrack Harris (Pollsters Kenya, 2013). The sample size was forty-eight. Eight participants for key informant interviews and forty for quantitative data. Sampling was done through purposive and systematic random sampling techniques. Data was collected using self-administered questionnaires and through Key Informant interviews. Quantitative data was analysed using descriptive statistics while qualitative data was analysed thematically. The study found out that communication plays a very significant role in electoral opinion polls in Kenya. The study recommends that the current legislation on electoral opinion polls should be evaluated to ensure objectivity and that the pollsters role of informing and educating citizens; and their rights to access information should not be compromised by law. It further recommends that the relevant bodies educate the public on the role and importance of polls.
\end{abstract}

Keywords: Communication, Electoral Opinion Polls, Pollsters 


\section{Introduction}

Public opinion polls, particularly those released in the lead up to an election, stimulate considerable debate and speculation amongst the media, the public and politicians. Opinion polls essentially attempt to capture public opinion, or the public's mood, on a given issue at a particular moment in time. Opinion polls are regularly conducted on voting intentions and leadership preferences, but can be undertaken on any social or commercial matter that the polling groups or commissioners of such polls determine (Macreadie, 2011).

Voters' opinion, perception, expectation and choice of electoral candidates are influenced by various factors. Voting behaviour in Africa is suggested to be predominantly influenced by some form of identity factor such as ethnicity, family lineages, religion, region, gender and party affiliation (Bratton and Van de Walle 1997; Barkan 1979; Ferree 2004, 2008; Lindberg et al 2008; as cited in Kimenyi et al., 2008). Empirical evidence supports the view that an African is primarily an "identity" voter. In essence, voting in Africa is in many cases nothing more than an ethnic census and individual voters use ethnicity as a proxy for the expected benefits for voting in a particular candidate.

While the personal expectations, preferences, tribe and party affiliation are central to the voter's decision making, the opinion of other voters on the viability and electability of the candidate is crucial. In Kenya, this influence is largely a media driven force, though informal local gatherings commonly termed as 'gumzo mtaani' or 'baraza' or 'bunge mtaani', campaign drives and recently social media following play a major role too. Traditionally, dummy (opinion) polls have mainly been done through local media outlets especially during primetime news cast and radio shows where voters 'cast' their votes through anonymous short messaging services (SMS), and through public opinion pollsters. Recently, digital electoral campaigns and online opinion polls surveys through social media platforms and emails are emerging avenues of electoral opinion polling. They are increasingly significant in electoral contexts and are being used by political parties, candidates and citizens to raise awareness and garner support (Williamson, Miller, \& Fallon, 2010).

Electoral opinion polls can exercise particular influence on the outcome of elections. McQuail (2005) noted that by publishing opinion polls or by stating editorially what the public view is on a given topic adds an element of potential influence. He further argued that when public opinion is embodied in media accounts, it acquires certain independence and this becomes an objective "social factor" that has to be taken into account by political and other actors. He concurs with Makulilo (2013) who posits that pre-election opinion polls, if conducted scientifically and impartially, are 
essential in projecting voting intentions of the electorate in a democratic polity. It follows therefore those electoral opinion polls as tools of communication may not only reflect the people's views but may also shape the views of others. That is, people may be influenced in how they vote by what they learn from an opinion poll (Ndati, Wambua, \& Mogambi, 2014).

Thus, when Mass Media conducts and publishes electoral opinion polls results and projections, they play a critical role in ensuring that voters have access to balanced, fair and objective poll results. While indeed communication channels provide significant information to the voters on the candidates, it is imperative to note that the information may also be quite distorting (Ndati et al., 2014). In 2005, electoral opinion polling in Kenya was seen to have come of age, with the predictions for the outcomes of the referendum vote on the proposed Constitution almost mirroring the actual outcome of the final vote. However, during Kriegler Commission (2008) hearings which were established to determine the main causes of the 2007/8 post-election violence, it was pointed out those public opinion poll (electoral) results contributed to the violence. Potentially, politicians, journalists and the general public alike did not grasp, a number of the key technical issues which determine views as to the accuracy of the results. These issues were pertaining to sample size (how can 2,000 people accurately represent the views of 16 million adults?), representation (maybe the survey is only carried out in areas favorable to individual political leaders) and the interpretation of data.

In effect, in instances where the survey data did not support their political inclinations, politicians felt that electoral opinion polls were flawed, manipulative and biased exercises - even publicity stunts! Many took every opportunity at public fora to discredit the poll results and the organizations that carried them out. The pollsters were blamed for failing to observe due (scientific and ethical) diligence in conducting and publishing accurate electoral opinion poll results. Likewise, media houses were accused of publishing erroneous electoral opinion polls results, with oversensationalized interpretations of the same.

Wolf (2009) affirms that any poll showing one leader less popular than another, or not appearing at all, or who had lost even a few percentage points over a given period of time was seen, nevertheless, as highly damaging. It was assumed that such results could create a 'bandwagon' effect by depressing further the votes for any candidate whose bid appeared unviable, or who was losing ground. Further, a local columnist in the Sunday Nation argues that:

It is absolutely unscientific and undemocratic to seek to pinpoint 'majority opinion' by throwing a few leading questions at individuals, chosen at random, who are likely to 
be totally ignorant of the social implications of the questions facing them. In any case, what exactly is the social value of knowing in advance which candidate a correspondent will vote for? Indeed, isn't it dangerous? In a society where real issues matter so little, Figures such as Steadman tosses around can powerfully sway the mass as to whom to vote for (P. Ochieng, SN, 8 April 2008)

This is a pointer of how publication of electoral opinion poll results can influence the voters to make undecided choice. Njogu (2008, quoted in 'Polling and the Kenyan media', Expression Today, as cited by Wolf, 2009) holds that polls can create a sense of confidence that one candidate is winning and lead to despair on the other side. In places where voters are not sure if their candidate is winning, they can cross over. They shape opinion of the electorates and that is why there is a concern of manipulation of polling groups by the political elites need to be addressed (Namunane, 2011).

This situation led the enactment of "the publication of electoral opinion polls Act no. 39 of 2012"; an act that sought to provide for the manner in which publication of electoral opinion polls is done in an open and objective way, while upholding scientific and ethical principles of opinion polls and research.

According to Tan (1985), Schramm defines communication as trying to share information, an idea, or an attitude. It is a process of active and interactive exchange between one or more transmitters and several receivers with the aim of getting people to adopt desirable and recommended attitudes and behaviour.

Duignan (2013) argues that the goal of polls reported in the media maybe used to inform, to entertain, to persuade, or to educate. In an electioneering period, the polls constitute one of the most systematic and objective sources of information for the citizens. They are a means through which journalists, politicians, business leaders and other elites - whether they like them or not - learn what the general public is thinking. Thus, it can be noted that electoral opinion polls are a form of communication and they should address the same functions of communication. In this regard, there is need for the common citizens to be aware of this form of communication so as to assist them in making informed and reliable voting decisions.

The way communication agents or opinion leaders present and assist in public interpretation of electoral opinion poll results have a potentially significant bearing on voters by imparting either a "demotivating" effect (when voters abstain from voting out of certainty that their candidate or party will win), a "motivating" effect (when individuals who had not intended to vote are persuaded to do so), or a "free-will" effect (when voters cast their ballots to prove the polls wrong). This study therefore sought to investigate 
the role of communication in creating awareness about electoral opinion polls and creating an interacting public-pollster interface.

\section{Methodology}

This study is set in a period when Kenya was in a general election campaigns and in the process of adopting the new legislation on regulation on publication of electoral opinion polls results - 2011 / 2013. During this period; the pollsters published electoral opinion poll results and parliament passed a law to regulate the publication of electoral opinion poll results in Kenya (Wambua, 2016). This study therefore sought to investigate the role of communication in creating awareness about electoral opinion polls and creating an interacting public-pollster interface.

This study targeted pollsters within Nairobi County in Kenya. There are twelve (12) registered public opinion and research companies in Kenya, four (4) of which are involved in electoral opinion polling (MSRA, 2013). We purposively sampled the 4 research companies dealing with electoral opinion polling namely: Ipsos - Synovate (50), Strategic Africa (30), Consumer Insight (35) and Infotrack Harris (45). The Figures in bracket indicate the number of employees in each company (Pollsters Kenya, 2013).

A sample size of forty-eight (48) was reached through purposive and systematic random sampling techniques. Eight (8) respondents for in-depth interviews [two (2) senior officers from each company] and forty (40) respondents for self-administered questionnaires were selected as described below

This technique consists of selecting every Kth case from a population. Thus,

$$
\text { Sampling constant, } \begin{aligned}
\mathrm{K} & =\text { Population } \div \text { Sample size } \\
& =160 \div 40 \\
& =4 \text { th }
\end{aligned}
$$

From a target population of 160, a number between 4 and 160 was selected at random. Quantitative data was collected using self-administered questionnaires. The questionnaires were structured and they had closed ended questions.

Qualitative data was collected through key informant interviews. The purpose of using interviews was to provide in - depth data that could not be captured in self-administered questionnaires. In addition, interviews yield higher response rates because it is difficult for a subject to completely refuse to answer questions or to ignore the interviewer. The researcher used interview schedule as an instrument for collecting data using a semi structured approach. During the interviews, data was recorded by both notes taking and recording, and later transcribed. 
Quantitative data was analyzed using Statistical Package for Social Sciences (SPSS ${ }^{\circledR}$ Version 20). This allowed simple tabulation and arrangement of responses in frequency distribution Tables and charts. Qualitative data on the other hand was thematically analyzed alongside the stated objective.

\section{Findings}

The objective of this study was to investigate the role of communication in creating awareness about electoral opinion polls. The researcher sought to understand the opinion of the respondents on what they thought was the role of communication in electoral opinion polls. Better still; whether they thought communication played any role in electoral opinion polls. The results were as follows:

\section{Factors that influence Electoral Opinion polling in Kenya}

The study sought to investigate what factors influences electoral opinion polling in Kenya. This was achieved through a factor analysis. The factor analysis in Table $\mathbf{1}$ below illustrated the factors that influence electoral opinion polling in Kenya. The analysis looked at how each factor scored in the factor analysis. It can be seen that "political parties in which candidates are affiliated” (.870) had more factor loading than all others. It means the respondents felt it had more influence on electoral opinion polling in Kenya. This was followed by presidential candidates with factor loading of (.860). Literary level of the respondents had a factor loading of (.837) while the "number of candidates vying for a particular political post" had (.814). Government had a factor loading of (.510) thus being the least factor that was perceived to influence electoral opinion polling in Kenya. In the overall the factor loading analysis below not only illustrates the main factors that influence electoral opinion polling in Kenya but also the extent of each. As mentioned, if the factor loadings are sort from the greatest to the smallest then the reader would see clearly the extent of each.

Table 1: Factor analysis on the factors that influence electoral opinion polling in Kenya

\begin{tabular}{|c|c|c|}
\hline \multicolumn{3}{|c|}{ Communalities } \\
\hline & Initial & Extraction \\
\hline $\begin{array}{c}\text { Media personnel } \\
\text { competence on reporting of } \\
\text { opinion poll results }\end{array}$ & 1.000 & .722 \\
\hline Presidential Candidates & 1.000 & .860 \\
\hline $\begin{array}{l}\text { Political Parties to which } \\
\text { candidates are affiliated }\end{array}$ & 1.000 & .870 \\
\hline $\begin{array}{c}\text { Business People and funding } \\
\text { agencies }\end{array}$ & 1.000 & 809 \\
\hline $\begin{array}{c}\text { Methodology used in } \\
\text { sampling and interviewing }\end{array}$ & 1.000 & .737 \\
\hline Government & 1.000 & .510 \\
\hline
\end{tabular}




\begin{tabular}{|c|c|c|}
\hline $\begin{array}{c}\text { Financial ability of the } \\
\text { Pollster }\end{array}$ & 1.000 & .809 \\
\hline $\begin{array}{c}\text { Accessibility to the Regions } \\
\text { to be polled }\end{array}$ & 1.000 & .753 \\
\hline $\begin{array}{c}\text { Legislation on Electoral } \\
\text { Opinion Polls }\end{array}$ & 1.000 & .691 \\
\hline $\begin{array}{c}\text { Time period for Conducting } \\
\text { Surveys }\end{array}$ & 1.000 & .614 \\
\hline $\begin{array}{c}\text { Literacy levels of the } \\
\text { Respondents }\end{array}$ & 1.000 & .837 \\
\hline $\begin{array}{c}\text { The number of political } \\
\text { parties to be on the ballot } \\
\text { box }\end{array}$ & 1.000 & .530 \\
\hline $\begin{array}{c}\text { The number of candidates } \\
\text { vying for a particular } \\
\text { political post }\end{array}$ & 1.000 & .814 \\
\hline \multicolumn{2}{|c|}{ Extraction Method: Principal Component Analysis. } \\
\hline
\end{tabular}

\section{Role of Communication in opinion polling}

Communication is seen as a process of active and interactive exchange between one or more transmitters and several receivers with the aim of getting people to adopt desirable and recommended attitudes and behavior. The goal of this communication is to inform, educate, persuade and to satisfy the receiver's needs. Hence, we went ahead to evaluate what role communication played in electoral opinion polling in Kenya.

Table 2: Respondents' opinion on whether there is any role of communication in electoral opinion polls

\begin{tabular}{|c|c|c|c|c|c|}
\hline \multicolumn{2}{|c|}{} & Frequency & Percent & $\begin{array}{c}\text { Valid } \\
\text { Percent }\end{array}$ & Cumulative Percent \\
\hline \multirow{3}{*}{ Valid } & Yes & 37 & 92.5 & 92.5 & 92.5 \\
\cline { 2 - 6 } & No & 3 & 7.5 & 7.5 & 100.0 \\
\cline { 2 - 6 } & Total & $\mathbf{4 0}$ & $\mathbf{1 0 0 . 0}$ & $\mathbf{1 0 0 . 0}$ & \\
\hline
\end{tabular}

It can be seen from Table 2 that $92.5 \%$ said communication has a role to play in electoral opinion polls while $7.5 \%$ did not agree with the issue. While the key objective of the study was whether there was any role of communication in creating awareness about electoral opinion polls, this had not been directly captured from the respondents as other related surveys assessed the most effective communication channels especially the ones used in disseminating and creating awareness of electoral opinion polls. Nonetheless, we sought to assess if there was any supported positive relationship between what the respondents' thought was the role of communication in electoral opinion polls and one of the factors that influenced electoral opinion polling in Kenya. Here, we referred to Table 1 developed earlier by selecting the factor that had the highest factor loading. Therefore, in Table 3, Pearson correlation was carried out between the factor representing "Political Parties to which candidates are affiliated" and 
"position on whether communication plays any role in electoral opinion polls”.

Table 3: Correlation test on the relationship between "Political Parties to which candidates are affiliated" and "position on whether communication plays any role in electoral opinion polls"

\begin{tabular}{|c|c|c|c|}
\hline \multicolumn{2}{|c|}{} & $\begin{array}{c}\text { Political } \\
\text { Parties to } \\
\text { which } \\
\text { candidates } \\
\text { are affiliated }\end{array}$ & $\begin{array}{c}\text { Communication plays any role in } \\
\text { electoral opinion polls }\end{array}$ \\
\hline \multirow{2}{*}{$\begin{array}{c}\text { Political Parties to } \\
\text { which candidates are } \\
\text { affiliated }\end{array}$} & $\begin{array}{c}\text { Pearson } \\
\text { Correlation }\end{array}$ & 1 & $.358^{*}$ \\
\cline { 2 - 4 } & Sig. (2-tailed) & & .023 \\
\cline { 2 - 4 } & $\mathrm{N}$ & 40 & 40 \\
\hline \multirow{2}{*}{$\begin{array}{c}\text { Communication plays } \\
\text { any role in electoral } \\
\text { opinion polls }\end{array}$} & $\begin{array}{c}\text { Pearson } \\
\text { Correlation }\end{array}$ & $.358^{*}$ & 1 \\
\cline { 2 - 4 } & Sig. (2-tailed) & .023 & 40 \\
\cline { 2 - 4 } & \multicolumn{2}{|c|}{40} & 40 \\
\hline \multicolumn{2}{|c|}{$*$ Correlation is significant at the 0.05 level (2-tailed). } \\
\hline \multicolumn{2}{|c|}{}
\end{tabular}

It can be seen that there exists moderate positive linear relationship between the two variables since the Pearson correlation was to $(.358 *)$. In the same respect the significance level was at (.023) meaning there was supported positive relationship to the same variables. On this backdrop, one could then proceed to affirm that communication did have some degree of influence in electoral opinion polls in Kenya. We then went ahead to run a multiple regression analysis in order to further determine whether communication in any way had a role in electoral opinion polls.

Table 4: Multiple regression analysis on "Political Parties to which candidates are affiliated" and "position on whether communication plays any role in electoral opinion polls”

\begin{tabular}{|c|c|c|c|c|c|c|}
\hline \multicolumn{7}{|c|}{ Coefficients } \\
\hline \multirow{2}{*}{\multicolumn{2}{|c|}{ Model }} & \multicolumn{2}{|c|}{$\begin{array}{l}\text { Unstandardized } \\
\text { Coefficients }\end{array}$} & \multirow{2}{*}{$\begin{array}{c}\text { Standardized } \\
\text { Coefficients } \\
\text { Beta } \\
\end{array}$} & \multirow[t]{2}{*}{$\mathrm{t}$} & \multirow[t]{2}{*}{ Sig. } \\
\hline & & B & Std. Error & & & \\
\hline \multirow{4}{*}{1} & (Constant) & 2.052 & .755 & & 2.716 & .010 \\
\hline & $\begin{array}{c}\text { Communication } \\
\text { channels do you use in } \\
\text { disseminating and } \\
\text { creating awareness of } \\
\text { electoral opinion polls }\end{array}$ & -.083 & .285 & -.140 & -.290 & .773 \\
\hline & $\begin{array}{c}\text { Most effective } \\
\text { communication channel }\end{array}$ & .066 & .340 & .094 & .194 & .847 \\
\hline & $\begin{array}{c}\text { Communication plays } \\
\text { any role in electoral } \\
\text { opinion polls }\end{array}$ & 1.450 & .709 & .343 & 2.044 & .048 \\
\hline
\end{tabular}


From the multiple regression analysis, it can be seen that communication channels used in disseminating and creating awareness of electoral opinion polls (.773) did not have any predictive significance on the variable representing factors influencing electoral opinion polls in Kenya. This was the same case to the most effective communication channels (.847). However, communication playing any role in electoral opinion polls (.048) significantly predicted the variable representing factors influencing opinion polling in Kenya.

In regard to the communication channels used to create awareness on electoral opinion polls, television was the most preferred channel at $72.5 \%$ while7.5\% settled for radio. Additionally, 5\% selected Facebook and Twitter while 2.5\% settled on Websites as shown in Table 5 and Figure 1 below.

Table 5: Descriptive statistics on communication channels used in disseminating and creating awareness of electoral opinion polls

\begin{tabular}{|c|c|c|c|}
\hline \multicolumn{2}{|c|}{} & Frequency & Percent \\
\hline \multirow{4}{*}{ Valid } & Television & 29 & 72.5 \\
\cline { 2 - 4 } & Radio & 3 & 7.5 \\
\cline { 2 - 4 } & Newspapers & 3 & 7.5 \\
\cline { 2 - 4 } & Facebook & 2 & 5.0 \\
\cline { 2 - 4 } & Twitter & 2 & 5.0 \\
\cline { 2 - 4 } & Websites & 1 & 2.5 \\
\cline { 2 - 4 } & Total & $\mathbf{4 0}$ & $\mathbf{1 0 0 . 0}$ \\
\hline
\end{tabular}

Figure 1: Pie chart on respondents' views on communication channels used in disseminating and creating awareness of electoral opinion polls

\section{Communication channels used in disseminating and creating awareness of electoral opinion polls}

Television Radio Newspapers Facebook Twitter Websites

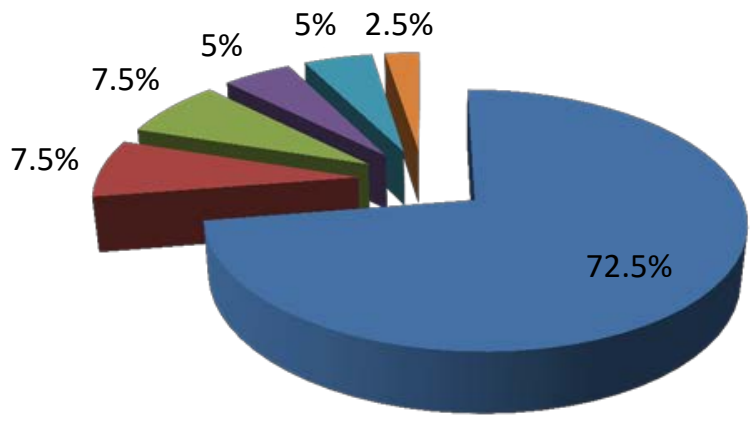

Related to the above, we took note of the respondents' opinion on the most effective communication channel used in disseminating and creating 
awareness of electoral opinion polls. The results are summarized in Table 6 and Figure 2 below.

Table 6: Respondents' views on the most effective communication channel

\begin{tabular}{|c|c|c|c|}
\hline \multicolumn{2}{|c|}{} & Frequency & Percent \\
\hline \multirow{4}{*}{ Valid } & Television & 18 & 45.0 \\
\cline { 2 - 4 } & Radio & 12 & 30.0 \\
\cline { 2 - 4 } & Newspapers & 5 & 12.5 \\
\cline { 2 - 4 } & Facebook & 2 & 5.0 \\
\cline { 2 - 4 } & Twitter & 3 & 7.5 \\
\cline { 2 - 4 } & Total & $\mathbf{4 0}$ & $\mathbf{1 0 0 . 0}$ \\
\hline
\end{tabular}

From the distributions above $45 \%$ of the respondents indicated that television was the most effective communication channel while 30\% indicated it was radio and $12.5 \%$ thought it was Newspapers, 5\% Facebook, 7.5\% Twitter and $0 \%$ for Websites.

Figure 2: Graphical representation of respondents' views on the most effective communication channel

\section{Respondents' views on the most effective communication channel}

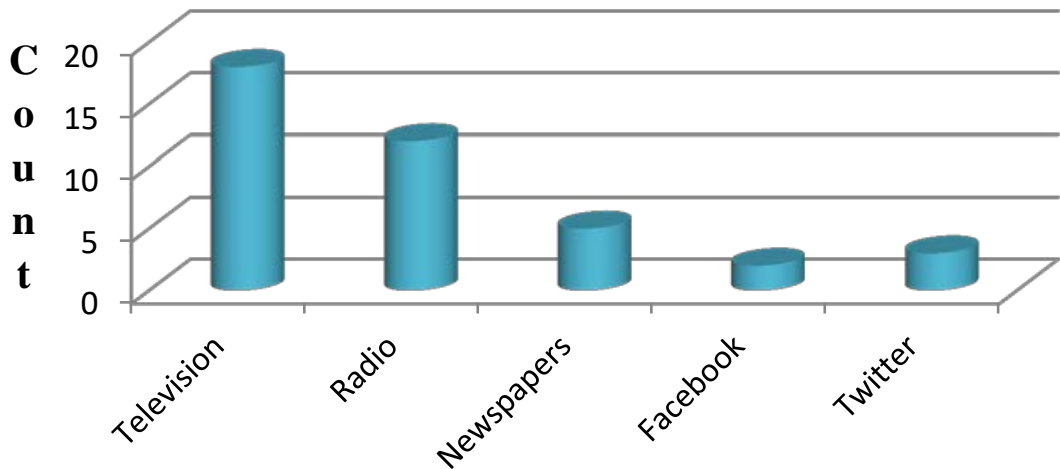

Type of Communication Channel

Further, the study established from the respondents the extent to which they thought the public are aware of the electoral opinion polls.

Table 7: Respondents' views on the extent of awareness of the public on electoral opinion polls

\begin{tabular}{|c|c|c|c|c|c|}
\hline \multicolumn{2}{|c|}{} & Frequency & Percent & Valid Percent & Cumulative Percent \\
\hline \multirow{4}{*}{ Valid } & Very Great Extent & 12 & 30.0 & 30.0 & 30.0 \\
\cline { 2 - 6 } & Great Extent & 20 & 50.0 & 50.0 & 80.0 \\
\cline { 2 - 6 } & Small Extent & 6 & 15.0 & 15.0 & 95.0 \\
\cline { 2 - 6 } & Very Small Extent & 2 & 5.0 & 5.0 & 100.0 \\
\cline { 2 - 6 } & Total & $\mathbf{4 0}$ & $\mathbf{1 0 0 . 0}$ & $\mathbf{1 0 0 . 0}$ & \\
\hline
\end{tabular}


From the results, it can be seen that $30 \%$ indicated the public were aware of electoral opinion polls to a "very great extent", $50 \%$ said it was to a "great extent", $15 \%$ "small extent" while $5 \%$ said it was to a "very small extent". The interest of the researcher was to evaluate whether the extent of awareness of the public on electoral opinion polls was statistically significantly different from the opinion whether voters believe and rely on the electoral opinion poll results. This scenario was captured through a paired sample t-test. See Table 8 below.

Table 8: Paired Sample t-test

\begin{tabular}{|c|c|c|c|c|c|c|c|c|c|}
\hline \multicolumn{10}{|c|}{ Paired Samples Test } \\
\hline & & \multicolumn{5}{|c|}{ Paired Differences } & \multirow[t]{3}{*}{$\mathrm{t}$} & \multirow[t]{3}{*}{ df } & Sig. \\
\hline & & \multirow[t]{2}{*}{ Mean } & \multirow[t]{2}{*}{\begin{tabular}{|c|} 
Std. \\
Deviation
\end{tabular}} & \multirow[t]{2}{*}{\begin{tabular}{|c} 
Std. \\
Error \\
Mean
\end{tabular}} & \multicolumn{2}{|c|}{$\begin{array}{l}\text { 95\% Confidence } \\
\text { Interval of the } \\
\text { Difference }\end{array}$} & & & $\begin{array}{c}(2- \\
\text { tailed })\end{array}$ \\
\hline & & & & & Lower & Upper & & & \\
\hline $\begin{array}{c}\text { Pair } \\
1\end{array}$ & $\begin{array}{c}\text { Do you think voters believe } \\
\text { and rely on the Electoral } \\
\text { Opinion Poll results? - } 44 . \text { In } \\
\text { your opinion, to what extent } \\
\text { do you think the publics are } \\
\text { aware of the electoral opinion } \\
\text { polls? }\end{array}$ & $\begin{array}{c}- \\
.52500\end{array}$ & .55412 & .08761 & -.70222 & $\mid-.34778$ & 5.992 & 39 & .000 \\
\hline
\end{tabular}

Evidently, with significance level of (.000) it can be said that voters believing and relying on the electoral opinion poll results was statistically significantly different from the extent of the public's awareness of the electoral opinion polls. In addition to the same the respondents that thought voters believe and rely on the electoral opinion poll results were $57.5 \%$ and those that did not were $42.5 \%$ as seen in Table 9 below.

Table 9: Respondents' views on whether voters believe and rely on the electoral opinion polls

\begin{tabular}{|c|c|c|c|c|c|}
\hline \multicolumn{6}{|c|}{ Do you think voters believe and rely on the Electoral Opinion Polls? } \\
\hline & & Frequency & Percent & Valid Percent & Cumulative Percent \\
\hline \multirow{3}{*}{ Valid } & Yes & 23 & 57.5 & 57.5 & 57.5 \\
\hline & No & 17 & 42.5 & 42.5 & 100.0 \\
\hline & Total & 40 & 100.0 & 100.0 & \\
\hline
\end{tabular}

The same data may be represented using a pie-chart as follows: 
Figure 3: Pie chart on respondents' views on whether voters believe and rely on the electoral opinion polls results

\section{Do voters believe and rely on the electoral opinion poll results?}

Yes No

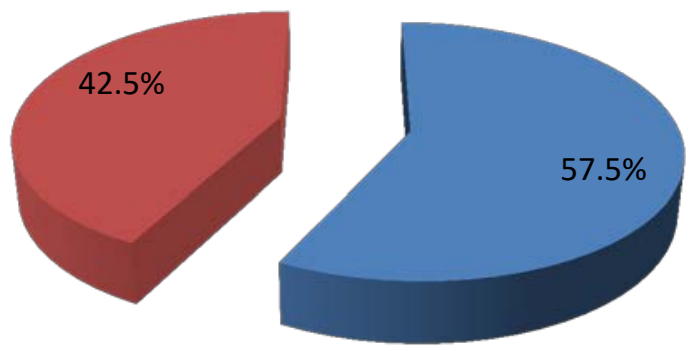

The next undertaking was to assess if there are any correlation between voters believe and reliance on the electoral opinion poll results and the extent of the same. This was combined by another correlation on whether the respondents thought politicians believe and rely on the electoral opinion poll results and the extent of this. See Table 10 below.

Table 10: Correlation matrix between voters believe and reliance on the electoral opinion poll results and the extent of the same

\begin{tabular}{|c|c|c|c|c|c|}
\hline \multicolumn{6}{|c|}{ Correlations } \\
\hline & & \begin{tabular}{|c|} 
Do you think \\
voters believe and \\
rely on the \\
Electoral Opinion \\
Poll results?
\end{tabular} & $\begin{array}{c}\text { If YES, to } \\
\text { what } \\
\text { extent? }\end{array}$ & $\begin{array}{l}\text { Do you think } \\
\text { politicians believe } \\
\text { and rely on the } \\
\text { Electoral Opinion } \\
\text { Poll results? }\end{array}$ & $\begin{array}{c}\text { If YES, to } \\
\text { what } \\
\text { extent? }\end{array}$ \\
\hline \multirow{3}{*}{$\begin{array}{c}\text { Do you think voters } \\
\text { believe and rely on } \\
\text { the Electoral } \\
\text { Opinion Poll } \\
\text { results? }\end{array}$} & $\begin{array}{c}\text { Pearson } \\
\text { Correlation } \\
\end{array}$ & 1 & $.473^{* *}$ & .064 & $.353^{*}$ \\
\hline & Sig. (2-tailed) & & .002 & .696 & .026 \\
\hline & $\mathrm{N}$ & 40 & 40 & 40 & 40 \\
\hline \multirow{3}{*}{$\begin{array}{c}\text { If YES, to what } \\
\text { extent? }\end{array}$} & $\begin{array}{c}\text { Pearson } \\
\text { Correlation }\end{array}$ & $.473^{* *}$ & 1 & $.380^{*}$ & $.678^{* *}$ \\
\hline & Sig. (2-tailed) & .002 & & .016 & .000 \\
\hline & $\mathrm{N}$ & 40 & 40 & 40 & 40 \\
\hline \multirow{3}{*}{$\begin{array}{c}\text { Do you think } \\
\text { politicians believe } \\
\text { and rely on the } \\
\text { Electoral Opinion } \\
\text { Poll Results? }\end{array}$} & $\begin{array}{c}\text { Pearson } \\
\text { Correlation }\end{array}$ & .064 & $.380^{*}$ & 1 & .172 \\
\hline & Sig. (2-tailed) & .696 & .016 & & .288 \\
\hline & $\mathrm{N}$ & 40 & 40 & 40 & 40 \\
\hline $\begin{array}{l}\text { If YES, to what } \\
\text { extent? }\end{array}$ & $\begin{array}{c}\text { Pearson } \\
\text { Correlation }\end{array}$ & $.353^{*}$ & $.678^{* *}$ & .172 & 1 \\
\hline
\end{tabular}




\begin{tabular}{|l|c|c|c|c|c|}
\hline & Sig. (2-tailed) & .026 & .000 & .288 & \\
\cline { 2 - 5 } & $\mathrm{N}$ & 40 & 40 & 40 & 40 \\
\hline & $* *$. Correlation is significant at the 0.01 level (2-tailed). \\
\hline
\end{tabular}

From the correlations above it can be seen that the respondents' perception on voters' belief and reliance on the electoral opinion poll results had moderate linear relationship (.473**) with the extent of the same. The significance level being at (.002) also indicated that such was a positive relationship. However, the relationships of the former with the respondents' perception on politicians believe and reliance on the electoral opinion poll results (.063) was a weak linear relationship. The significance level at (.696) showed that the two case scenarios did not have any supported relationship. But respondents' perception on politician's belief and reliance on the electoral opinion poll results had supported relationship (.016) with the extent of the respondents' thought on voters believe and reliance on the electoral opinion poll results. Additionally, in both cases of extent of both politicians and voters believing and relying on the electoral opinion poll results emerged as a strong linear relationship and very significant at (.000). This demonstrated high positive correlation implications.

Lastly, it was critical to establish whether believe and reliance of electoral opinion poll results both for politicians and voters significantly predicted public awareness of the electoral opinion polls. This was demonstrated using a multiple regression analysis in Table $\mathbf{1 1}$ below.

Table 11: Multiple regression analysis on belief and reliance of electoral opinion poll results and public awareness of the electoral opinion polls

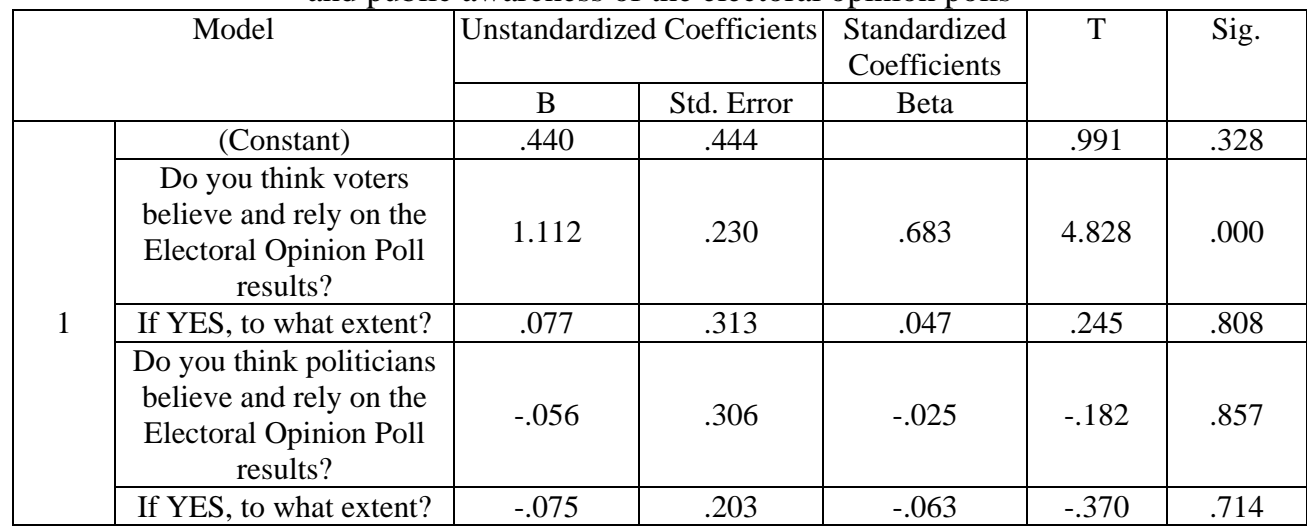

From the multiple regression above it can be seen that only voters' belief and reliance on the electoral opinion poll results (.000) significantly predicted the extent of public awareness of the electoral opinion polls. In the case of politicians believe and reliance on electoral opinion poll results (.857) significantly predict public’s awareness of the electoral opinion polls. 
The other multiple regression sought to establish the predictive significance of awareness of the legislation on publication of electoral opinion polls and zeal to take part in the opinion polls. Other independent variables incorporated in this multiple regression analysis included the perceived differences in the way electoral opinion polls were conducted before and after the legislation and perception on whether legislation influenced voters' access to credible, reliable and representative polls.

Table 12: Multiple regression analysis on the influence of legislation aspect on participation in electoral opinion polls

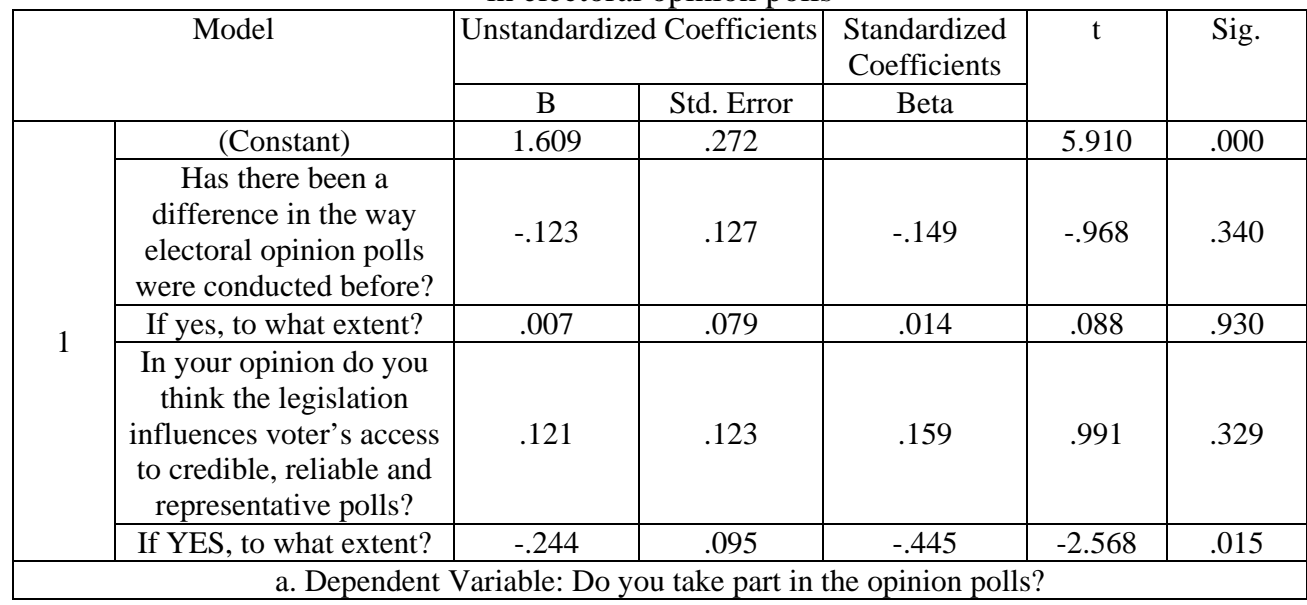

From the multiple regression output above only the extent of legislation influence on voters' access to credible, reliable and representative polls (.015) significantly predicted participation in the opinion polls.

\section{Qualitative Results}

The interviewees were general and research managers of various pollsters. The main pollsters that the interviewees worked for were namely: IPSOS - Synovate, Infotrack Haris and Strategic Africa. Consumer Insight did not participate in this study. Therefore, two of the interviewees were from Strategic Africa, one from IPSOS-Synovate and the other Infotrack Haris. The interviewees indicated to have worked for their respective pollsters for a number of years. For instance, both the General Manager and Research Manager at Strategic Africa indicated to have worked there for a period of eight and seven years respectively. The Research Managers at Infotrack Haris and IPSOS - Synonate failed to disclose their period of service in their respective company.

All the interviewees indicated that their work environment was good and they have been at home with it. This is what one of them had to say: 
"Indeed, having worked at IPSOS-Synovate for a long time I appreciate the environment around this place. I am sure this has not only benefited me but even other staff members."

The other interview captured the opinion of the respondents on what they thought were the functions of opinion polls. In general, they all expressed that they act as intermediate channels where the public get to know and anticipate the future. These were some of their views:

Interviewee 1: "Well, am reminded of the time when Kenya never used to have pollsters. Therefore, the citizens did not have a way to predict current pressing issues politics, economic and social matters. However, this has changed since in our company we have succeeded to capitalize on current issues or affairs and relate them to the future of Kenyans. This way they have been able to make informed decisions like in choosing candidates during elections.”

Another interviewee stated:

"Opinion polls simply put Kenyans in an interactive forum where they get to express their most heartfelt views on issues pressing them. Then, through adequate sampling and forecasting the opinion polls present a scenario that may help to inform policy in the country".

In relation to the role of communication in creating awareness about electoral opinion polls some of the interviewees had this to say:

"Communication is at the heart of any polls because that is the only way to create an interactive process with the targeted audience."

In general, most of the interviewees indicated that communication played a very significant role especially in helping to inform and educate the public on the intended message of the polls.

In the case of what might be the level of public awareness on the importance of the electoral opinion polls all respondents said such was significant; in other words, that the public were fully aware that opinion polls played significant role in their decision making about the future. In regard to communication strategies in place to create awareness on electoral opinion polls to the public the respondents mentioned television, radios, newspapers and social media. For instance, one of the interviewees had this to say:

"We ensure that our communication strategies tie to what our targeted audience use daily for communication. Moreover, we target the main channels of communication to reach to the audience."

The above interview results were what we managed to obtain from the interviewees. It was not possible to capture everything due to their busy 
work schedules. However, the findings so far helped to acquire insights in light of the objectives of this research project.

\section{Discussion and conclusion}

Literature review findings did not illustrate fully the role of communication in creating awareness about electoral opinion polls in Kenya. However, in the primary data this was achieved in a number of ways. First, majority of respondents confirmed the role of communication in electoral opinion polls. The researcher even went ahead and established a positive correlation in Table $\mathbf{3}$ based on the major factor influencing electoral opinion polls (political parties), there existed a supported relationship. This in a way shows the significant role of communication when it comes to electoral opinion polls in Kenya. Inasmuch as the multiple regression in Table 4 did not show that all aspects of communication had predictive significance in electoral opinion polls at least one (Communication plays any role in electoral opinion polls) did. It would have been absurd not to scientifically prove the role of communication in creating awareness about electoral opinion polls in Kenya because opinion polls being the key medium and then assuming not to have any influence would be untenable. On this qualitative basis actually evidenced in the interviews results makes the study's findings practical and realistic.

Lastly, the correlation in Table 10: the relevance of seeing the correlational relationship between voters believe and reliance on the electoral opinion poll results and that of politicians was because the two serve as the main subjects of electoral opinion poll results. Therefore, noting on their perception and how they correlated was a very important aspect of this study. For instance, given that the extent of voters and politicians believe and reliance on the electoral opinion poll results had supported relationship; it means (politicians and voters) as subjects of electoral opinion polls had the same expectations. This again may be confirmed by the fact that both voters and politicians were equally subjects of the electoral opinion poll results.

\section{References:}

1. Archer, S. (2009, June). Why do Kenyans Vote Along Ethnic Lines? (Unpublished Master's Thesis). University of Oslo, Norway. Retrieved May, 15, 2013 from https://www.duo.uio.no/bitstream/handle/.../siax-xmasteroppgave.pdf

2. Duignan, B. (2013). Political parties, interest groups, and elections. New York: Britannica Educational Pub. in association with Rosen Educational Services. Retrieved from http://public.eblib.com/choice/publicfullrecord.aspx?p=934410 
3. Ireri, M., \& Wolf, T. (2010, November). Public Opinion Polls: Transforming Africa into an Information Based Society. Paper session presented at the Marketing and Social Research Association, Nairobi. $\quad$ Retrieved September 15, 2012 from http://www.msra.or.ke/documents/conference/2010/MSRA 2010

4. Kenya Gazette Supplement Acts, 2011\{Supplement No. 173 (Acts No. 39 of 2012)\}. The Publication of Electoral Opinion Polls Act. Printed and Published by the Government Printer, Nairobi.

5. Kimenyi, Mwangi S. and Romero, Roxana G. (2008). "Identity, Grievances, and Economic Determinants of Voting in the 2007 Kenyan Elections". Economics Working Papers. Paper 200838. http://digitalcommons.uconn.edu/econ_wpapers/200838

6. Kriegler Commission Report (2007). Report of the Independent Review Commission on the General Elections held in Kenya on 27 December, 2007; chap 4. Retrieved October 10, 2012 from http://kenyastockholm.files.wordpress.com/2008/09/the_kriegler_rep ort.pdf

7. Macreadie, R. (2011). Research Paper: Public Opinion Polls. Library, Department of Parliamentary Services, Parliament of Victoria, (No. 3, July 2011), 47. http://doi.org/10.13140/2.1.2546.4646

8. Makulilo, A. B. 2013. "Poll-'pollution'? The politics of numbers in the 2013 elections in Kenya”, The African Review 40, 1: 1-32.

9. Marketing \& Social Research Association Member's Registry, 2013. Retrieved January 25, 2013 from http://www.msra.or.ke/members.asp

10. McQuail, D. (2005). McQuail's Mass Communication Theory, Sage Publication, London.

11. Namunane, B. (2011, December 14). Khalwale Bill seeks to Regulate Opinion Polls. Daily Nation. Retrieved September, 15, 2012, from http://mobile.nation.co.ke/Khalwale-Bill-seeks-to-regulate-opinionpolls-/-/1292/1289588/-/format/xhtml/item/0/-/kws8s9/-/index.html

12. Ndati, N., Wambua, P., \& Mogambi, H. (2014). The impact of legislation on electoral opinion polls in Kenya. European Scientific Journal, 10(34). $\quad$ Retrieved from http://eujournal.org/index.php/esj/article/view/4836

13. Tan, A. (1985). Mass Communication Theories and Research $\left(2^{\text {nd }}\right.$ ed.). John Wiley and Sons, Inc.

14. Thomas P. Wolf (2009). 'Poll Poison'?: Politicians and polling in the 2007 Kenya election, Journal of Contemporary African Studies, 27:3, 279-304.

15. Duignan, B. (2013). Political parties, interest groups, and elections. New York: Britannica Educational Pub. in association with Rosen 
Educational

Services.

Retrieved

from

http://public.eblib.com/choice/publicfullrecord.aspx?p=934410

16. Macreadie, R. (2011). Research Paper: Public Opinion Polls. Library, Department of Parliamentary Services, Parliament of Victoria, (No. 3, July 2011), 47. https://doi.org/10.13140/2.1.2546.4646

17. Ndati, N., Wambua, P., \& Mogambi, H. (2014). The impact of legislation on electoral opinion polls in Kenya. European Scientific Journal, 10(34). Retrieved from http://eujournal.org/index.php/esj/article/view/4836

18. Wambua, P. K. (2016). Law and Electoral Opinion Polls: The Effects of Legislation on Electoral Opinion Polls in Kenya. Germany: LAP LAMBERT Academic Publishing. Retrieved from https://www.lappublishing.com/

19. Williamson, A., Miller, L., \& Fallon, F. (2010). Behind the Digital Campaign. London: Hansard Society. 